\title{
SUITABILITY EVALUATION OF CROP MANAGER FOR BORO RICE PRODUCTION
}

\author{
M. M. Alam ${ }^{1 *}$, M. A. Ali2 , M. A. Rahman' ${ }^{2}$, M. S. Hossain ${ }^{2}$ and M. S. Rahman 3 \\ ${ }^{1}$ Department of Agronomy, Shahid Akber Ali Science and Technology College, Thakurgaon \\ ${ }^{2}$ Department of Agronomy, Hajee Mohammad Danesh Science and Technology University \\ ${ }^{3}$ Department of Agricultural Chemistry, Hajee Mohammad Danesh Science and Technology University \\ Corresponding Author, E-mail: sagor hstu@yahoo.com
}

Key words: Crop manager, fertilizers, variety, yield, boro season

\begin{abstract}
The experiment was conducted at a farmer's field, Nashipur, Dinajpur during the period from January to June, 2014 during the Boro season. There were three fertilizer treatments: $F_{1}$ : Fertilizer Recommended by Farmers Practice (FP), $\mathrm{F}_{2}$ : Fertilizer Recommended by Nutrient Management (NM) and $\mathrm{F}_{3}$ : Fertilizer Recommended by SRDI. The variety BRRI dhan28 was used as the test crop for the experiment. It may be concluded that nutrient management recommended fertilizer dose performed better than recommended fertilizer dose by SRDI and farmers practiced. So, it may be inferred that increase the crop yield in Boro season farmers could apply N, P, K and S at the rate of 238,60, 60 and $20 \mathrm{~kg} \mathrm{ha}^{-1}$, respectively as nutrient manager compared to that of recommended doze.
\end{abstract}

\section{Introduction}

Rice (Oryza sativa L) is one of the most extensively cultivated cereal crops for more than 50\% of the world's population. It is the second highest consumed cereal in the world after wheat (Kumari et al., 2014). Among the rice growing countries, Bangladesh ranks fourth in respect of both area and production in the world (BBS, 2015). Rice is intensively cultivated in Bangladesh covering about 74\% of arable land (AIS, 2001). In Bangladesh, there are three rice growing seasons viz. Aus, Aman, and Boro. Bangladesh produced around 19.1 million tons of rice from Boro, 13.02 million tons from Aman and 2.6 million tons from Aus in 2014-15 (BBS, 2015). Rice production area is decreasing due to human population pressures. Therefore, attempts should be made to increase the yield per unit area by proper nutrient management, which is the most effective means to achieve the goal.

The use of fertilizer has been progressively increasing and this trend is likely to continue in future if the nation desires to produce more agricultural products to meet the increasing demand. The continuous and unbalanced use of the chemical fertilizers under intensive cropping systems has been considered to be the main cause for declining crop yield and environmental degradation. Nitrogen, phosphorus, potassium, zinc and sulfur are nutrient elements most commonly applied by rice farmers. But these inorganic fertilizers do not usually match the requirement of crops. In general, farmers apply higher rates of nitrogen $(\mathrm{N})$, phosphorus (P) and, potassium (K). This higher application of $\mathrm{N}, \mathrm{P}$ and $\mathrm{K}$ is often responsible for low yields and poor crop quality because optimum application of $\mathrm{N}, \mathrm{P}$ and $\mathrm{K}$ is beneficial on physiological and biochemical requirements in plant growth. For Boro rice production, nitrogen is the key nutrient required in the largest quantities. Rice plants require a large amount of nitrogen at the early and mid-tillering stage to maximize the number of panicles (Datta, 1981). Phosphorus is the second major nutrient for plants and adequate phosphorus enhances many 
Alam et al.

aspects of plant physiology, including the fundamental processes of photosynthesis, $\mathrm{N}$-fixation, flowering, fruiting and maturation (Wilson et al., 1998). About 41\% of the soils of Bangladesh contained P below the critical level (Portch and Islam 1984). Potassium is the third major nutrient for plant and is necessary for several basic physiological functions, such as synthesis of protein and starch, normal cell division and growth. Sulphur plays a unique role in plant metabolism and its main function is constituent of amino acids, biotin, Vit B, and coenzyme A. Zinc is important for chlorophyll synthesis, auxin formation, activation of dehydrogenase enzyme, stabilization of ribosomal fractions of plants.

Nutrient deficiencies can be corrected by the judicious application of chemical fertilizers. Farmers do not apply uniform fertilizers in all plots of a national map unit due to different productivity level, but they desire uniform yield from all plots. However, farmers have their own conceptions about soil fertility and considered the factors that favor crop performance, such as plot size, location, previous fertilizer use, weed infestation and pest infestation (Saleque et al., 2008). In most cases farmers use excess and imbalance fertilizer doses thus soil fertility as well as soil quality are degrading significantly. On the other hand, sustainable farming systems require soil fertility status to be maintained at a level that supports satisfactory plant growth while minimizing nutrient loss to the environment (Betteridge et al., 2008).Nutrient Manager for rice is a computer-based decision support tool, enabling the rapid development of fertilizer guidelines for specific rice fields. It contains questions, which can be quickly answered with existing knowledge of farmers and technicians. After answering the questions, a printable fertilizer guideline is provided. The present investigation was, therefore, undertaken to evaluate the performance of nutrient manager on the yield and yield contributing characters of boro rice.

\section{Materials and Methods}

The experiment was conducted at a farmer's field, Nashipur, Dinajpur during the period from January to June, 2014 during the Boro season. The experimental field is a medium high land having sandy loam soil with $\mathrm{pH}$ 5.97. There were three fertilizer treatments: $\mathrm{F}_{1}$ : Farmers Practice (FP), $\mathrm{F}_{2}$ : Fertilizer Recommended by Nutrient Manager (NM) by fertilizer (238-60-6020 N P K S Kg ha $\left.{ }^{-1}\right)$ and $F_{3}$ : Fertilizer Recommended by SRDI (304, 39, 102, 86 and 4 N P K $\mathrm{S} \mathrm{Kg} \mathrm{ha}{ }^{-1}$. The variety BRRI dhan28 was used as the test crop. The experiment was laid out in a Randomized Complete Block Design (RCBD) with four (4) replications. All the treatments were randomly allocated to the experimental plots within each block. Layout of the experiment was done maintaining plot to plot distance $75 \mathrm{~cm}$ and replication to replication distance $1.0 \mathrm{~m}$. The total numbers of plots were 12 and the size of unit plot was $10 \mathrm{~m}^{2}(4.0 \mathrm{~m} \times 2.5 \mathrm{~m})$. Rice seedlings were transplanted at 35 days after sowing with a spacing of $25 \mathrm{~cm} \times 15 \mathrm{~cm}$ at two seedlings hill-1 on 13 February 2014. Various intercultural operations were done for maintaining the normal growth and development of the crop. Harvest maturity of the rice field was determined when $90 \%$ of the grains became golden yellow in color. Five hills (excluding border hills) were selected randomly from each unit plot and collected by uprooting prior to harvesting for recording data on yield components and yield. The grain yields were recorded from each plot and moisture percentage reading was taken by moisture meter and grain weight was adjusted at 14\% moisture. Data were statistically analyzed and the significance of mean differences was adjudged by the Duncan's Multiple Range Test (DMRT) with the help of a computer package (MSTATC) program (Gomez and Gomez, 1984). 
Suitability Evaluation of Crop Manager for Boro Rice Production

\section{Results and Discussion}

Plant height: The results showed that plant height of BRRI dhan28 was not significantly affected by the different treatments (Table 1). Plant height varied from $89.50 \mathrm{~cm}$ in $\mathrm{F}_{3}$ treatment to $93.50 \mathrm{~cm}$ in $\mathrm{F}_{2}$ treatment. The tallest plant $(93.50 \mathrm{~cm})$ was recorded in the treatment $\mathrm{F}_{2}$ (Recommended by $\mathrm{NM}$ ) and the shortest plant $(89.50 \mathrm{~cm}$ ) was obtained in the treatment $\mathrm{F}_{3}$ (Recommended by SRDI). It might be due to smaller increase of all the fertilizers, which did not affect the growth and development of plants remarkably.

Number of total tillers hill ${ }^{-1}$ : It was observed that the number of total tillers was significantly influenced by different fertilizer treatments at $1 \%$ level of probability (Table 1). The highest number of total tillers hill ${ }^{-1}$ (18.50) was produced by the fertilizer dose recommended by nutrient manager (NM) which was followed by the fertilizer dose recommended by farmers practice (17.50) and the lowest number of total tillers hill-1 ${ }^{-1}(14.75)$ was found from the fertilizer dose recommended by SRDI. These results are well supported with the findings of Parvez et al. (2008) who found increased number of total tillers hill ${ }^{-1}$ with the increased use of fertilizers.

Number of effective tillers hill-1 ${ }^{-1}$ : There was a significant effect of different fertilizer treatments on the production of effective tillers hill ${ }^{-1}$ of rice plants (Table 1 ). The number of tillers hill ${ }^{-1}$ due to different treatments varied from 13.38 to 17.13 . The highest number of effective tillers hill ${ }^{-1}$ (17.13) was found in the treatment $\mathrm{F}_{2}$ (recommended by NM) which was statistically similar to the treatment $\mathrm{F}_{1}$ (recommended by FP). It might be due to smaller change of all the fertilizers from recommended rates. The minimum number of tillers hill-1 (13.38) was found in the treatment $\mathrm{F}_{3}$ (recommended by SRDI). Similar results were also obtained by Balakrisnan and Natarajaratnan (1986).

Panicle length: The length of panicle of BRRI dhan28 was significantly influenced by the application of fertilizers at $1 \%$ level of probability (Table 1). The highest panicle length $(27.25$ $\mathrm{cm}$ ) was found in $\mathrm{F}_{2}$ (recommended by $\mathrm{NM}$ ). The lowest panicle length $(22.13 \mathrm{~cm}$ ) was observed in the treatment $\mathrm{F}_{3}$ (recommended by SRDI) which was statistically similar to the treatment $F_{1}$ (recommended by FP). These results are in agreement with Rahman et al. (2009) who found increased panicle length with the application of different fertilizer dozes.

Number of total spikelets panicle ${ }^{-1}$ : Result showed that number of total spikelets panicle ${ }^{-1}$ of BRRI dhan28 responded significantly to different fertilizer treatments (Table 1). The total number of spikelets panicle-1 varied from 122.50 to 141.00 . The highest number of spikelets panicle $^{-1}$ (141.00) was obtained from the treatment $F_{2}$ (recommended by NM) which was statistically similar with respect to spikelets panicle $e^{-1}$ to the treatment $F_{1}$ (recommended by FP). The lowest number of spikelets panicle $e^{-1}$ (122.50) was obtained from the treatment $F_{3}$ (recommended by SRDI). These results were supported by the findings of Mondal et al. (1990) and Halder et al. (2000).

Number of filled grains panicle ${ }^{-1}$ : Results presented in the Table 1 showed a significant effect of various rates fertilizer supplied from respective fertilizers on the number of filled grains panicle $e^{-1}$ of RRRI dhan28. The number of filled grains panicle ${ }^{-1}$ of different treatments ranged from 109.75 to 127.50 . The highest number of filled grains panicle $e^{-1}(127.50)$ was found in the treatment $F_{2}$ (recommended by $N M$ ) which was statistically similar to the treatments $F_{1}$ (recommended by FP). It might be due to smaller reduction of all the fertilizers from 
Alam et al.

recommended rates, which did not affect the growth and development of plants remarkably. The lowest number of filled grains panicle ${ }^{-1}$ (109.75) was found in the treatment $\mathrm{F}_{3}$ (recommended by SRDI). These results support the findings of Rahman et al. (2009) who found increased number of filled grains panicle ${ }^{-1}$.

Number of sterile spikelets panicle ${ }^{-1}$ : The variation in the number of sterile spikelets panicle $e^{-1}$ due to different fertilizer treatments was significant at 5\% level of significance (Table 1). The results indicated that the number of sterile spikelets panicle ${ }^{-1}$ varied from 12.50 to 17.25 . The highest number of sterile spikelets panicle ${ }^{-1}(17.25)$ was produced by the treatments $F_{1}$ (recommended by FP). The lowest number of sterile spikelets panicle ${ }^{-1}(12.50)$ was produced by the treatment $\mathrm{F}_{3}$ (recommended by $\mathrm{SRDI}$ ) which was statistically similar to the treatments $\mathrm{F}_{2}$ (recommended by NM).

Weight of 1000 grains (g): It was observed that 1000 grain weight of BRRI dhan28 was significantly influenced $(p<0.01)$ by the application of different fertilizer levels. The 1000-grain weight ranged from $22.42 \mathrm{~g}$ to $23.72 \mathrm{~g}$. The highest 1000 -grain weight $(23.72 \mathrm{~g})$ was recorded from the treatments $\mathrm{F}_{2}$ (recommended by $\mathrm{NM}$ ) which was statistically similar to the treatments $F_{1}$ (recommended by FP) while the lowest 1000 -grain weight $(22.42 \mathrm{~g}$ ) was obtained in the treatment $\mathrm{F}_{3}$ (recommended by SRDI). Similar results were reported by Rahman et al. (2009) and Parvez et al. (2008).

Moisture content (\%): The moisture content of BRRI dhan28 was not changed by the different fertilizer doses. The moisture content ranged from $22.22 \%$ to $23.30 \%$. The highest moisture content $(23.30 \%)$ was obtained by the treatments $\mathrm{F}_{3}$ (recommended by SRDI) and the lowest moisture content $(22.22 \%)$ was produced by the treatment treatments $\mathrm{F}_{2}$ (recommended by $\mathrm{NM})$.

Grain yield (tha ${ }^{-1}$ ): Results showed that the grain yield of BRRI dhan28 responded significantly to the different fertilizer treatments (Table 1). The grain yield due to various treatments ranged from 6.10 to $7.52 \mathrm{t} \mathrm{ha}^{-1}$. The highest grain yield $\left(7.52 \mathrm{t} \mathrm{ha}^{-1}\right)$ was obtained in the treatments $\mathrm{F}_{2}$ (recommended by NM). It might be due to higher number of tillers as well as panicles hill ${ }^{-1}$, higher number of grain per panicle, highest thousand grain-weight and higher harvest index in compared to that of $F_{1}$ and $F_{3}$ treatments. The lowest grain yield $\left(6.10 \mathrm{t} \mathrm{ha}{ }^{-1}\right)$ was obtained in the treatments $\mathrm{F}_{3}$ (recommended by $\mathrm{SRDI}$ ) which was statistically similar to the treatments $\mathrm{F}_{1}$ (recommended by FP). It was due to the lowest number of tillers as well as panicles per hill and lowest number of grains per panicle. Khan et al. (2007) reported that grain yield was significantly increased due to application of different chemical fertilizers. These results are also in agreement with the findings of Rani et al. (2001), Rahman et al. (2009) and Parvez et al. (2008).

Straw yield (tha $\left.{ }^{-1}\right)$ : Straw yields varied significantly with different treatments. The yields of straw ranged from 10.00 to $11.02 \mathrm{t} \mathrm{ha}^{-1}$ (Table 1$)$. The highest straw yield $\left(11.02 \mathrm{t} \mathrm{ha}^{-1}\right)$ was obtained from the treatment $F_{2}$ (recommended by NM) and the lowest value $\left(10.00 \mathrm{t} \mathrm{ha} \mathrm{a}^{-1}\right.$ ) with treatment $\mathrm{F}_{3}$ (recommended by $\mathrm{SRDI}$ ) which was statistically similar to the treatment $\mathrm{F}_{1}$ (recommended by FP). The treatments may be ranked in the order of $F_{2}>F_{1}>F_{3}$ in terms of straw yield. Rahman et al. (2009) reported that the application of urea-N in combination with other chemical fertilizers increased the straw yields of rice. 
Biological yield: The biological yield obtained from different treatments ranged from 16.10 to $18.54 \mathrm{t} \mathrm{ha}^{-1}$. The highest biological yield $\left(18.54 \mathrm{t} \mathrm{ha}^{-1}\right)$ was recorded in the treatments $\mathrm{F}_{2}$ (recommended by NM) which was statistically similar to the treatments $\mathrm{F}_{1}$ (recommended by FP). The lowest biological yield $\left(16.10 \mathrm{t} \mathrm{ha}^{-1}\right.$ ) was obtained in the treatments $\mathrm{F}_{3}$ (recommended by SRDI) which was statistically similar to the treatments $F_{1}$ (recommended by FP). This result was in agreement with Rahman et al. (2009).

Harvest index (\%): Harvest index of BRRI dhan28 was significantly influenced by the different fertilizer levels (Table 1). The highest harvest index (40.56\%) was obtained from the treatments $\mathrm{F}_{2}$ (recommended by $\mathrm{NM}$ ) and the lowest harvest index (37.89\%) was obtained in the treatments $\mathrm{F}_{3}$ (recommended by SRDI).

Nutrient content in rice grain and straw: The $\mathrm{N}$ content in rice grain and straw was significantly influenced by the application of various rates of fertilizers (Fig.1).The highest $\mathrm{N}$ content in grain $(1.392 \%)$ and straw $(0.845 \%)$ was observed in the treatments $\mathrm{F}_{2}$ (recommended by $\mathrm{NM}$ ) and the lowest $\mathrm{N}$ content of grain $(1.301 \%)$ and straw $(0.721 \%)$ was noted in the treatments $\mathrm{F}_{3}$ (recommended by SRDI). The results revealed that $\mathrm{N}$ content in rice grain was higher than that of straw. A significant increase in $\mathrm{N}$ content in rice grain and straw due to the application of fertilizers has been reported by many investigators (Bhaskaram and Krisna, 2009).

Results in Fig. 2 indicated that phosphorus content in the grain of BRRI dhan28 varied significantly due to different fertilizer treatments. The highest $\mathrm{P}$ content in grain $(0.273 \%)$ and straw $((0.128 \%))$ was found in $\mathrm{F}_{2}$ (recommended by $\left.\mathrm{NM}\right)$ and the lowest value $(0.222 \%)$ and $(0.097 \%)$ in grain and straw was noted in the treatments $\mathrm{F}_{1}$ (recommended by FP). Application of different fertilizer doses showed more pronounced effect in increasing the $\mathrm{P}$ content in rice grain and straw. An increase in $\mathrm{P}$ content both in rice grain and straw due to the application chemical fertilizers was reported by many investigators (Parvez et al., 2008). Similar results were also obtained by Kadu et al. (1991).

The potassium content both in grain and straw of BRRI dhan28 was significantly influenced due to application of various level fertilizers (Fig.3). The highest $\mathrm{K}$ content in rice grain $(0.284 \%)$ and straw $(0.502 \%)$ were recorded in the treatment $\mathrm{F}_{2}$ (recommended by $\mathrm{NM}$ ) and the lowest $\mathrm{K}$ content in grain $(0.258 \%)$ and straw $(0.395 \%)$ was recorded in the treatments $F_{3}$ (recommended by SRDI). The K content in straw was much higher than that in grain. These results are in agreement with Singh et al. (2001) who revealed that K content in grain and straw was increased due to application of different chemical fertilizers. The results were also in agreement with the findings of Bahmaniar and Mashaee (2010).

The sulphur content both in grain and straw of BRRI dhan28 was significantly influenced by the combined use of different dose fertilizers (Fig.4). The highest $\mathrm{S}$ content of grain $(0.171 \%)$ and straw $(0.089 \%)$ was obtained in the treatments $\mathrm{F}_{2}$ (recommended by $\mathrm{NM}$ ) and the lowest value of grain $(0.148 \%)$ and straw $(0.077 \%)$ was noted in the treatments $\mathrm{F}_{3}$ (recommended by SRDI). Chandel et al. (2003) reported that application of sulphur from inorganic fertilizers increased the $\mathrm{S}$ content both in grain and straw of rice.

\section{Conclusion}

From the above findings it may be concluded that nutrient manager fertilizer dose performed better than recommended fertilizer dose by SRDI and farmers practiced.. So, it may be inferred that increase the crop yield in Boro season then apply N, P, K and S at the rate of $238 \mathrm{~kg}, 60$ $\mathrm{kg}, 60 \mathrm{~kg}$ and $20 \mathrm{~kg} \mathrm{ha}^{-1}$, respectively compared to that of recommended doze. 
Alam et al.

Table 1. Effects of different rates of fertilizer on the yield contributing characters and yield of Rice var. BRRI dhan28

\begin{tabular}{|c|c|c|c|c|c|c|c|c|c|c|c|}
\hline Treatment & $\begin{array}{l}\text { Plant } \\
\text { height } \\
(\mathrm{cm})\end{array}$ & $\begin{array}{c}\text { Effective } \\
\text { tillers } \\
\text { hill }^{-1}\end{array}$ & $\begin{array}{c}\text { Panicle } \\
\text { length } \\
\text { (cm) }\end{array}$ & $\begin{array}{c}\text { Total } \\
\text { spikelets } \\
\text { panicle } \\
\text { (no.) }\end{array}$ & $\begin{array}{c}\text { Filled } \\
\text { grains } \\
\text { panicle }{ }^{-1} \\
\text { (no.) }\end{array}$ & $\begin{array}{c}\text { Sterile } \\
\text { spikelets } \\
\text { panicle }{ }^{-1} \\
\text { (no.) }\end{array}$ & $\begin{array}{l}\text { 1000- } \\
\text { grain } \\
\text { weight } \\
\text { (g) }\end{array}$ & $\begin{array}{c}\text { Grain } \\
\text { yield } \\
\left(\text { tha }^{-1}\right)\end{array}$ & $\begin{array}{c}\text { Straw } \\
\text { yield } \\
\left(\mathrm{t} \mathrm{ha}^{-1}\right)\end{array}$ & $\begin{array}{c}\text { Biological } \\
\text { yield } \\
\left(\mathrm{t} \mathrm{ha}^{-1}\right)\end{array}$ & $\begin{array}{c}\text { Harvest } \\
\text { index } \\
(\%)\end{array}$ \\
\hline $\begin{array}{l}\mathrm{F}_{1}= \\
\text { Farmers } \\
\text { practice }\end{array}$ & 90.50 & $16.25 a$ & $23.13 b$ & $130.75 \mathrm{ab}$ & $112.00 \mathrm{ab}$ & $17.25 a$ & $23.20 \mathrm{a}$ & $6.82 b$ & $10.75 \mathrm{ab}$ & $17.57 \mathrm{ab}$ & $38.82 b$ \\
\hline $\begin{array}{l}\mathrm{F}_{2}= \\
\text { Nutrient } \\
\text { manager }\end{array}$ & 93.50 & $17.13 \mathrm{a}$ & $27.25 a$ & $141.00 \mathrm{a}$ & $127.50 \mathrm{a}$ & $13.50 b$ & $23.72 \mathrm{a}$ & $7.52 \mathrm{a}$ & $11.02 \mathrm{a}$ & $18.54 \mathrm{a}$ & $40.56 a$ \\
\hline $\mathrm{F}_{3}=\mathrm{SRDI}$ & 89.50 & $13.38 b$ & $22.13 b$ & $122.50 \mathrm{~b}$ & $109.75 b$ & $12.50 \mathrm{~b}$ & $22.42 b$ & $6.10 \mathrm{~b}$ & $10.00 \mathrm{~b}$ & $16.10 \mathrm{~b}$ & $37.89 c$ \\
\hline CV (\%) & 3.58 & 7.58 & 7.55 & 5.01 & 7.90 & 21.90 & 1.88 & 3.66 & 6.45 & 5.04 & 3.46 \\
\hline
\end{tabular}

In a column, the treatment Means having similar letter(s) do not differ significantly by DMRT

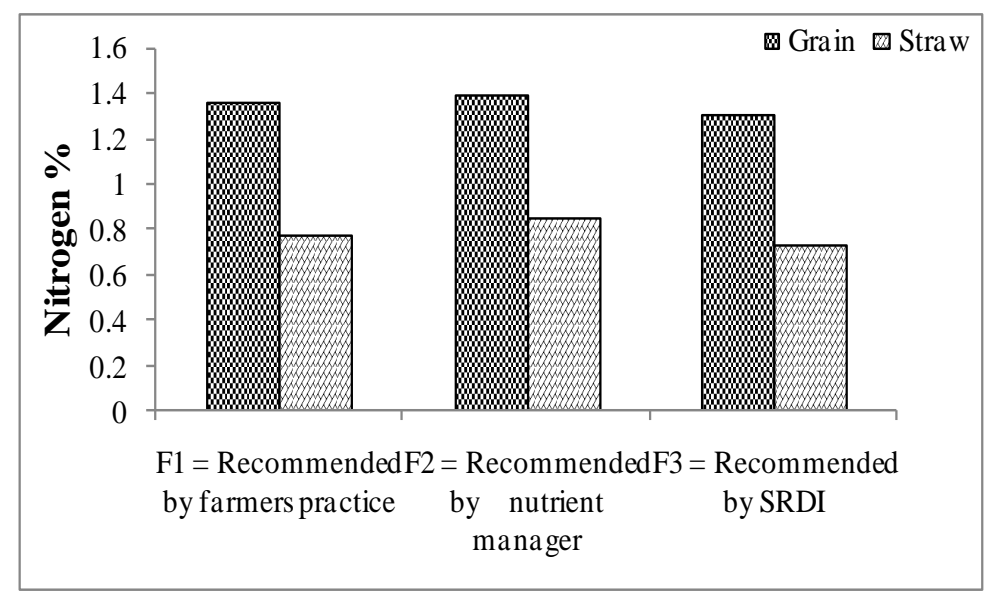

Fig. 1. Effects of different rates of fertilizer on $\mathrm{N}$ content in grain and straw of rice var. BRRI dhan28

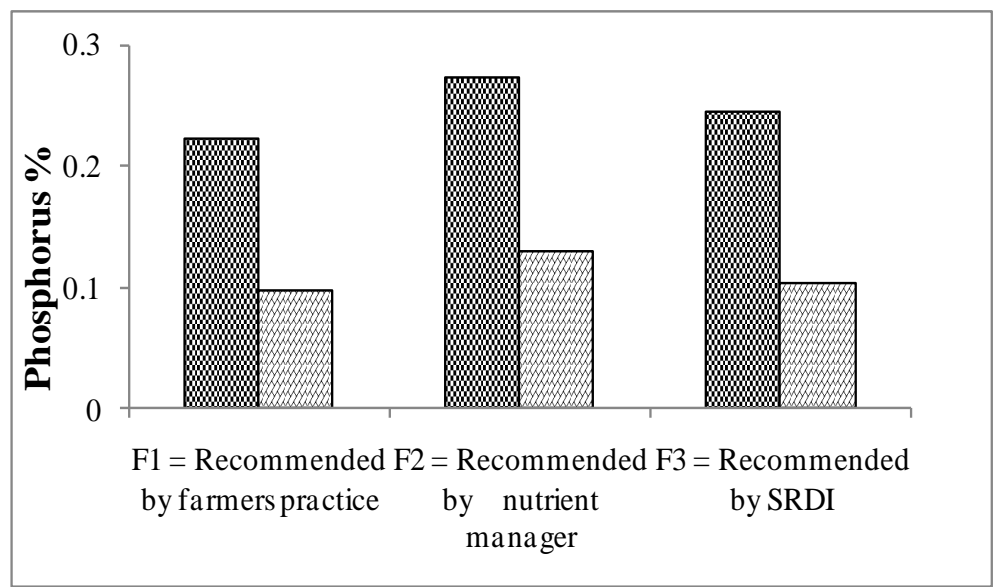

Fig. 2. Effects of different rates of fertilizer on $P$ content in grain and straw of rice var. BRRI dhan 28 


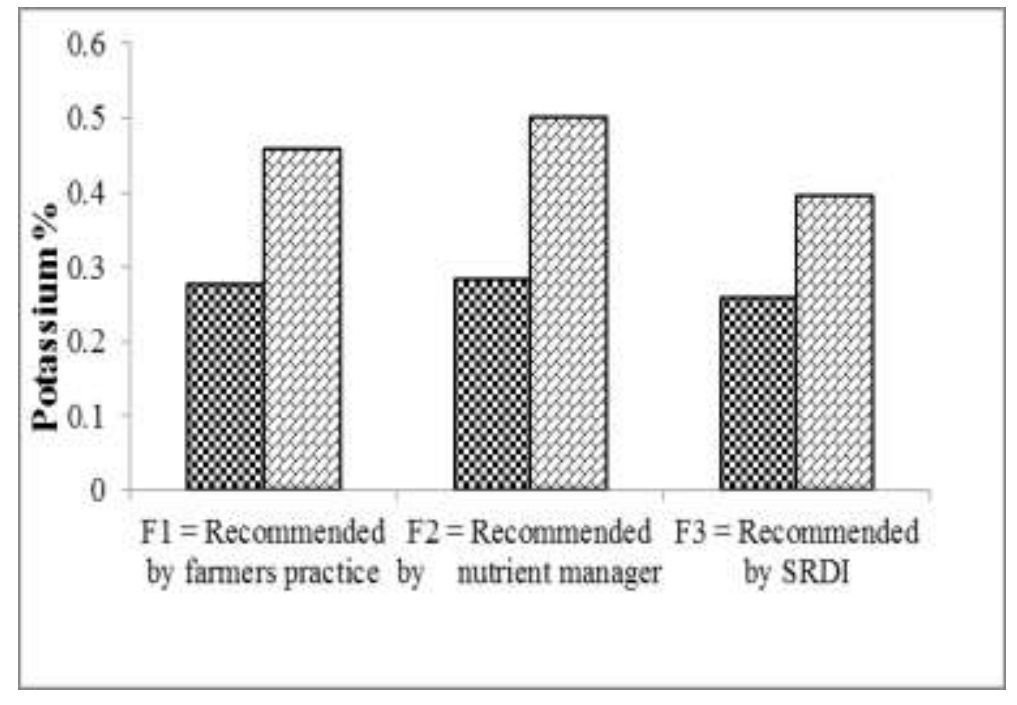

Fig. 2. Effects of different rates of fertilizer on $\mathrm{K}$ content in grain and straw of var. BRRI dhan 28

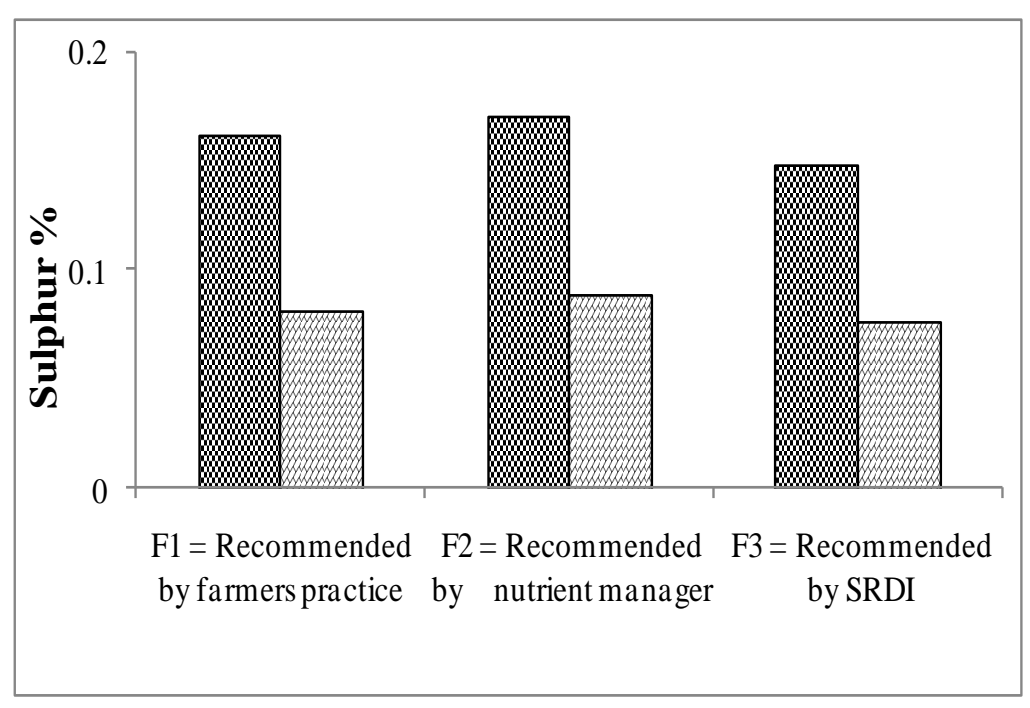

Fig. 2. Effects of different rates of fertilizer on S content in grain and straw of var. BRRI dhan28 
Alam et al.

\section{References}

AIS. 2001.Krishi Diary. Agricultural Information Service, Khamarbari, New Airport Road, Farmgate, Dhaka, Bangladesh. pp. 20-22.

Bahmaniar, M. A. and Mashaee, S. S. 2010. Influences of nitrogen and potassium top dressing on yield and yield component as well as their accumulation in rice. African J. Biotech. 9 (18): 2648-2653.

Balakrishnan, K. and Natarajaratnan, N. 1986. Effect of Zn supplement on yield and components in certain rice varieties. Madras Agric. J. 73 (10): 598-600.

BBS, (Bangladesh Bureau of Statistics). 2015. Estimates of Boro Rice (Husked), 2014-15. pp. 1-6.

Betteridge, K., Schnug, E. and Haneklaus, S. 2008. Will site specific nutrient management live up to expectation? Agric. Forestry Res. 4(58): 283-294.

Bhaskaram, U. and Krisna, D. 2009.Effect of organic farming on soil fertility, yield and quality of crops in the tropics. $16^{\text {th }}$ International Plant Nutrition Colloquium 2009, Sacramento, California, p. 89-90.

Chandel, R. S., Singh, K., Singh, A. K. and Sudhakar, P. C. 2003. Effect of sulphur nutrition in rice (Oriza sativa L.) and mustard (Brassica junceaL. Czern and Coss) grown in sequence. Indian Physiol. 8(2): 155-159.

Datta, S. K. 1981. Principles and practices of rice production. International Rice Research Institute. Los Banos, Philippines. p 349.

Gomez, K. A. and Gomez, A.A. 1984.Statistical procedure for agricultural research. Intl. Rice Res. Inst. John Wiley and Sons, New York. pp. 139-240.

Halder, K. P., Chowdhury, M. J. U. and Ahmed, N. 2000.Effect of planting methods and nitrogen rates on the yield and yield components of Ausrice grown under rained condition at the coastal area of Bangladesh.Bangladesh J. Argil. Sci. 27 (1): 59-64.

Kadu, P. B., Bhoyar, V. S. and Thakare, R. S. 1991. Effect of NPK-FYM blended manurial mixtures on performance of rice. J. Soil Crop. 1 (2): 172-174.

Khan, M. U., Qasim, M. and Khan, I. U. Qasim, M. and Khan, I. U. 2007.Effect of integrated nutrient management on crop yields in rice-wheat cropping system.Sarhad.J. of Agril. 23 (4): 1019-1025.

Kumari, P., G. C. Mishra, A. K. Pant, G. Shukla and S. N. Kujur.2014. Comparison of forecasting ability of different statistical models for productivity of rice (Oryza sativa L.) in India.The Ecoscan. 8(3-4): 193-198.

Mondal, S. S., Joyaram, D. and Pradhan, B. K. 1990.Effect of fertilizer and farmyard manure on the yield components of rice (Oryza sativa L.). Environ. Eco. 8 (1): 223-226.

Parvez, M. S., Islam M. R., Begum, M. S., Rahman, M. S. and Abedin Miah, M. J. 2008.Integrated use of manure and fertilizers for maximizing the yield of BRRI dhan30. J. Bangladesh Soc. Agric. Sci. Technol., 5(1\&2): 257-260.

Portch, S. and Islam, M. S. 1984 Nutrient status of some of the more important agricultural soils of Bangladesh. In "Proceedings of International Symposium on Soil Test Crop Response Studies", Bangladesh Agricultural Research Council and Soil Science Society of Bangladesh, pp. 97-106. 
Rahman, M. S. Islam, M. R. Rahman, M. M. and Hossain, M. I. 2009. Effect of cowdung, Poultry manure and Urea-N on the yield and nutrient uptake of BBRI Dhan29.Bangladesh Res. Pub. J. 2(2): 552-558.

Rani, R., Srivastava, O. P and Rani, R. 2001.Effect of integration of organics with fertilizer N on rice and N Uptake.Fertilizer News. 46(9): 63-65.

Saleque M. A., Uddin M. K., Ferdous A. K. M and Rashid M. H. 2008.Use of farmers' empirical knowledge to delineate soil fertility-management zones and improved nutrient-management for lowland rice.Commu. Soil Sci. Plant Anal, 39:25-45.

Wilson C. E., Bollich P. K. and Norman, R. J. 1998. Nitrogen application timing effects on nitrogen efficiency of dry-seeded rice. Soil Sci. Soc. Am. J. 62: 959-964. 